\title{
A systematic review of effectiveness and safety of different regimens of levonorgestrel oral tablets for emergency contraception
}

\author{
Mohammad Shohel ${ }^{1 * \dagger}$, Mohammad Mahfuzur Rahman ${ }^{1 \dagger}$, Asif Zaman ${ }^{1 \dagger}$, Mir Muhammad Nasir Uddin ${ }^{2 \dagger}$,
} Md Mamun Al-Amin ${ }^{1+}$ and Hasan Mahmud Reza ${ }^{1+}$

\begin{abstract}
Background: Unintended pregnancy is a complex phenomenon which raise to take an emergency decision. Low contraceptive prevalence and high user failure rates are the leading causes of this unexpected situation. High user failure rates suggest the vital role of emergency contraception to prevent unplanned pregnancy. Levonorgestrel - a commonly used progestin for emergency contraception. However, little is known about its pharmacokinetics and optimal dose for use. Hence, there is a need to conduct a systematic review of the available evidences.

Methods: Randomized, double-blind trials were sought, evaluating healthy women with regular menstrual cycles, who requested emergency contraception within $72 \mathrm{~h}$ of unprotected coitus, to one of three regimens: $1.5 \mathrm{mg}$ single dose levonorgestrel, two doses of $0.75 \mathrm{mg}$ levonorgestrel given $12 \mathrm{~h}$ apart or two doses of $0.75 \mathrm{mg}$ levonorgestrel given $24 \mathrm{~h}$ apart. The primary outcome was unintended pregnancy; other outcomes were side-effects and timing of next menstruation.

Results: Every trial under consideration successfully established the contraceptive effectiveness of levonorgestrel for preventing unintended pregnancy. Moreover, a single dose of levonorgestrel $1.5 \mathrm{mg}$ for emergency contraception supports its safety and efficacy profile. If two doses of levonorgestrel $0.75 \mathrm{mg}$ are intended for administration, the second dose can positively be taken $12-24 \mathrm{~h}$ after the first dose without compromising its contraceptive efficacy. The main side effect was frequent menstrual irregularities. No serious adverse events were reported.

Conclusions: The review shows that, emergency contraceptive regimen of single-dose levonorgestrel is not inferior in efficacy to the two-dose regimen. All the regimens studied were very efficacious for emergency contraception and prevented a high proportion of pregnancies if taken within $72 \mathrm{~h}$ of unprotected coitus. Single levonorgestrel dose $(1.5 \mathrm{mg}$ ) can substitute two $0.75 \mathrm{mg}$ doses 12 or $24 \mathrm{~h}$ apart. With either regimen, the earlier the treatment is given, the more effective it seems to be.
\end{abstract}

Keywords: Levonorgestrel, Oral contraceptive, Emergency contraception, Two dose regimen, Postcoital contraception, Single dose strategy, Contraceptive efficacy, Unintended pregnancy, Postcoital hormonal contraceptives

\footnotetext{
* Correspondence: mohammadnsu@yahoo.com

${ }^{\dagger}$ Equal contributors

'Department of Pharmaceutical Sciences, North South University, Dhaka

1229, Bangladesh

Full list of author information is available at the end of the article
} 


\section{Background}

Access to emergency contraception and its need for increasing awareness and convenience is very important nowadays. Post-coital or emergency contraception is a simple, reliable and effective strategy. However, the complications associated with the emergency contraception are needed to be addressed before its full potential is realized. The most challenging aspect is that healthcare personnel and potential users are both quite ignorant of this approach [1]. The other major obstacle which prevents the extensive use of emergency contraception is that both potential users and doctors believe that such approaches to contraception are accompanied with frequent and severe side-effects [2-4]. Previous data suggest that, the significance of emergency contraceptive pills cannot be ignored any longer, since one million abortions and two million unwanted pregnancies could be prevented in the U.S. each year if its widespread use could be ensured [5].

Currently available commonly acknowledged hormonal method of post-coital contraception was first described by Yuzpe and Lancee [6] and Yuzpe et al. [7]. Based on the findings of these authors, each dosage included the combination of $200 \mu \mathrm{g}$ ethinyl oestradiol and $2 \mathrm{mg}$ dl-norgestrel given in two divided doses where the second dose was given after $12 \mathrm{~h}$ of the first dose, within $72 \mathrm{~h}$ of unprotected intercourse. Though the pregnancy rate was only $1.6 \%$, there was a relatively high prevalence of side-effects $(\sim 50 \%$ of cases). Side effects including nausea and/or vomiting, this leads to decreased compliance of patients [8]. Even though the Yuzpe regimen has become an established and recommended method of emergency contraception, there is a need to reduce the incidence of adverse effects while maintaining effectiveness [9].

Levonorgestrel (LNG) is a synthetic, biologically active progestogen, structurally related to 19-nortestosterone, which may be used alone or in combination with estrogens for the prevention of unintended pregnancies following unprotected coitus [10]. LNG is only sought as a supportive method for irregular rather than regular use and LNG is intended to be used immediately after intercourse but prior to pregnancy has become recognized [11]. LNG is also safe and effective in women with type I and type II diabetes [12]. Levonorgestrel-only emergency contraceptive has an efficiency rate of $89 \%$ if it is used correctly within $72 \mathrm{~h}$ after unprotected intercourse. LNG also diminishes the risk of pregnancy, following a single act of mid-cycle unprotected sexual intercourse, from $8 \%$ on average, to $1.1 \%$ [13]. Every time the dose is delayed $12 \mathrm{~h}$ after starting emergency contraception treatment it reduces efficacy by about 50\% [14].

LNG works in several different mechanisms depending on the cycle day of unprotected intercourse and the day on which the treatment is started. LNG may inhibit the process of ovulation, fertilization or implantation [15-20]. However, there is no direct clinical indication that supports these mechanisms. Emergency contraception is effective only before a fertilized egg is implanted because it can't disrupt an existing pregnancy, i.e., emergency contraceptives are not abortifacient [21]. Several studies suggested that the lowest concentration required to prevent ovulation is $0.48 \mathrm{nmol} / \mathrm{L}$ [22]. Hence, appropriate dosing is critical to ensure the prevention of pregnancy.

For emergency contraception, there is pharmacokinetic evidence for two doses of $0.75 \mathrm{mg}$ of levonorgestrel, $12 \mathrm{~h}$ apart [23-25]. The oral bioavailability of levonorgestrel is $>90 \%$. However, this has been reported to depend on the dosage form and to be affected by a concomitant administration of estrogens [26,27]. The peak concentration after a single oral dose of $0.75 \mathrm{mg}$ of levonorgestrel is attained within $1 \mathrm{~h}$ after administration, with a half-life that is within 20 to $60 \mathrm{~h}$ [23-25]. However, not much is known about the pharmacokinetics of a single dose of $1.5 \mathrm{mg}$ of levonorgestrel in fertile women during the periovulatory period of the menstrual cycle [23].

The purpose of this study was to compare the efficacy and side-effects of two treatments, when administered up to $72 \mathrm{~h}$ after unprotected coitus: a single dose of $1.5 \mathrm{mg}$ levonorgestrel; and two separate doses of $0.75 \mathrm{mg}$ levonorgestrel that are given 12 and $24 \mathrm{~h}$ apart. The main outcomes were pregnancy rates, proportions of pregnancies prevented, side-effects and timing of the first menstrual period after treatment. We also thought to analyze the effect of treatment delay on the efficacy of contraception.

Our idea was that all the regimens in consideration would have similar efficacy in preventing pregnancy. We also analyzed how the timing of contraception in relation to coitus influenced treatment effectiveness.

\section{Methods}

\section{Criteria for inclusion and exclusion}

Randomized, double blind studies were selected for this review. The literature which included women of fertile age, compared one and/or two doses of levonorgestrel taken in different regimens and described the kinetics or dynamics of the drug were also reviewed. Reasons for exclusion including non-English studies, literatures involving non-human models, studies which compared levonorgestrel with other emergency hormonal contraceptives and publications concerned with dosage forms other than oral tablets.

\section{Data sources}

MEDLINE, HighWire Press, Elsevier, PubMed, Google Scholar, Springerlink, EBSCO, and Wolters Kluwer Health databases were searched from 1967-2012 using the key terms emergency contraception, postcoital contraception, 
postcoital contraceptives, levonorgestrel, single dose and double dose. The trials identified with our search strategy were initially checked for duplicates and relevance for the review by looking at the titles and abstracts. If it was not possible to exclude a publication by looking at the title or the abstract, the full paper was retrieved. Decisions on which trials to include were independently made by two reviewers. Bibliographies of retrieved articles for additional studies were also searched. We limited the search to English-language reports involving humans. Studies were selected where patient outcomes or pharmacokinetics were assessed with alternative levonorgestrel-only emergency contraception (EC).

\section{Data extraction}

Two authors independently reviewed the search results for reports of studies of any design of hormonal drugs taken orally for contraception, immediately before or after each act of intercourse during one or more menstrual cycles. We found 114 relevant studies (Figure 1). We excluded eighty one trials from our review because they contained incomplete information on the drug regimen, number of pregnancies, or the duration of data collection and four because only a partial report or abstract was available. Of the remaining 29 studies, 14 provided data on regimens containing levonorgestrel. The others described studies comparing with other compounds and therefore those ten studies were omitted from this review. Discrepancies were resolved by discussion and consultation with other reviewers including clinicians if needed.

\section{Outcome measures}

Outcome measures included pregnancy rates, percent of pregnancies prevented and side-effects. From kinetic viewpoint, the area under the plasma concentration versus time curve to last time, area under the plasma concentration curve to infinity, peak plasma concentration, time of peak plasma concentration, elimination rate constant and terminal half-life were observed. We also assessed the outcome by comparing the length of the cycle, bleeding patterns, follicular rupture and ovulation period, ovulatory dysfunction, length of luteal phase, day of maximal luteal serum progesterone (P4), follicular outcome, luteal serum glycodelin and the effect on total lutenizing hormone (LH).

Finally, we used the Preferred Reporting Items for Systematic reviews and Meta-Analyses (PRISMA) criteria for reporting systematic reviews of studies that evaluate healthcare interventions, a quality appraisal tool.

\section{Results}

Six of the 14 trials were randomized, double blind studies of a single regimen. Eight trials included multiple groups of women given levonorgestrel tablets of different doses. The method of treatment allocation was not described, so we considered each group as a separate case series. The total number of treatment groups analyzed across all studies was 28. Of these groups, 11 evaluated tablets containing $0.75 \mathrm{mg}$ levonorgestrel, and the others evaluated tablets containing other doses (Table 1).

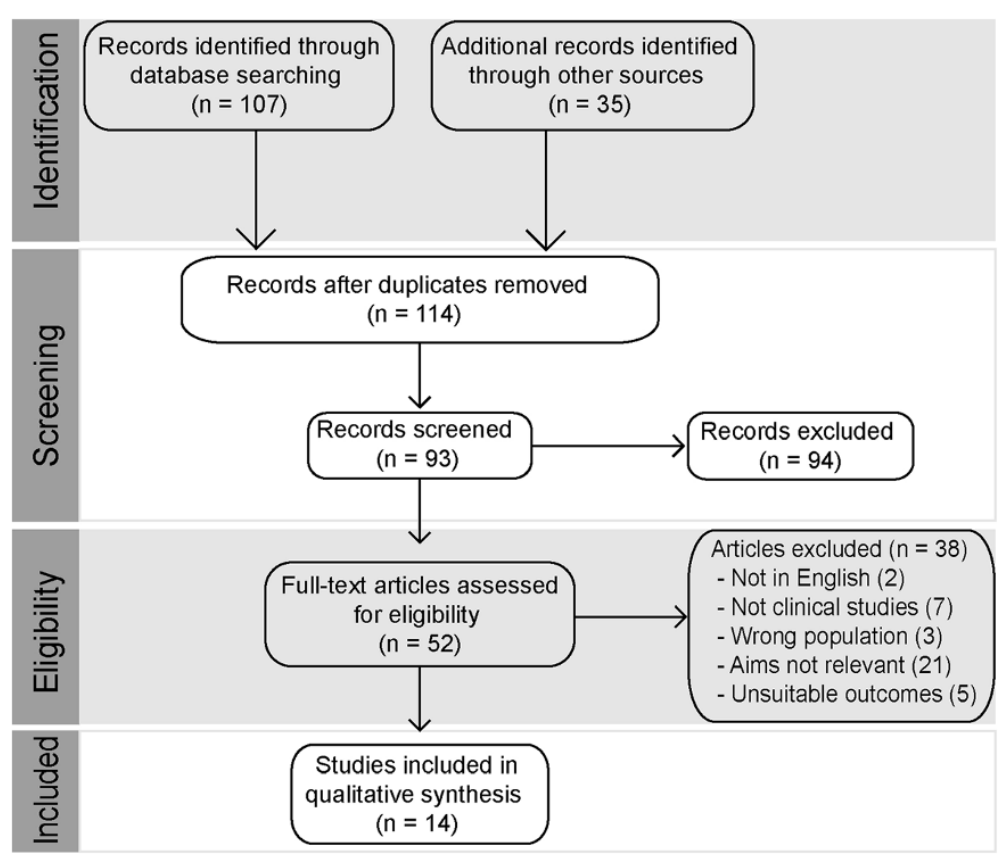

Figure 1 Study selection flow diagram. 
Table 1 Study design and demographic data

\begin{tabular}{|c|c|c|c|c|c|c|}
\hline \multirow[t]{2}{*}{ Study (year) [ref] } & \multirow[t]{2}{*}{ Country } & \multicolumn{2}{|c|}{$\begin{array}{l}\text { Population } \\
\text { characteristics }\end{array}$} & \multicolumn{3}{|l|}{ Study design } \\
\hline & & $\begin{array}{l}\text { No. of } \\
\text { subjects }\end{array}$ & $\begin{array}{l}\text { Age } \\
\text { (years) }\end{array}$ & Type of trial & Dose & Dose frequency \\
\hline $\begin{array}{l}\text { Arowojolu et al., (2002) } \\
\text { [30] }\end{array}$ & Nigeria & 1160 & $19-35$ & Prospective comparative study & $\begin{array}{l}0.75 \mathrm{mg} \& \\
1.5 \mathrm{mg}\end{array}$ & Once \& two split doses $12 \mathrm{~h}$ apart \\
\hline Croxatto et al., (2004) [33] & $\begin{array}{l}\text { Chile, Dominican } \\
\text { Republic }\end{array}$ & 58 & $18-40$ & Two-center, randomized, double-blind, placebo-controlled study & $0.75 \mathrm{mg}$ & Two doses given $12 \mathrm{~h}$ apart, or a single dose \\
\hline Dada et al., (2010) [31] & Nigeria & 3022 & $20-33$ & $\begin{array}{l}\text { Randomized, controlled, double-blind, multicentre, } \\
\text { non-inferiority trial }\end{array}$ & $\begin{array}{l}0.75 \mathrm{mg} \& \\
1.5 \mathrm{mg}\end{array}$ & Two doses, $12 \mathrm{~h}$ apart vs. a single dose \\
\hline Durand et al., (2001) [18] & Mexico & 45 & $29-35$ & Randomized, comparative study & $0.75 \mathrm{mg}$ & $\begin{array}{l}\text { Two doses taken } 12 \mathrm{~h} \text { apart, at } 0 \mathrm{~h} \& \text { after } \\
48 \mathrm{~h}\end{array}$ \\
\hline Durand et al., (2005) [34] & Mexico & 30 & $29-35$ & Randomized, comparative study & $0.75 \mathrm{mg}$ & $\begin{array}{l}\text { Two doses taken } 12 \mathrm{~h} \text { apart, at } 0 \mathrm{~h} \& \text { after } \\
48 \mathrm{~h}\end{array}$ \\
\hline Gainer et al.., (2007) [28] & Chile & 12 & $18-32$ & - & $1.5 \mathrm{mg}$ & Once \\
\hline $\begin{array}{l}\text { Hapangama et al., (2001) } \\
\text { [19] }\end{array}$ & Scotland & 12 & $26-41$ & Prospective, randomized, double-blind, crossover study & $0.75 \mathrm{mg}$ & Two doses given $12 \mathrm{~h}$ apart \\
\hline $\begin{array}{l}\text { Johansson et al., (2002) } \\
\text { [23] }\end{array}$ & Dominican Republic & 5 & $18-45$ & Randomized, comparative study & $\begin{array}{l}0.75 \mathrm{mg} \& \\
1.5 \mathrm{mg}\end{array}$ & $\begin{array}{l}\text { Once, two doses given } 12 \mathrm{~h} \text { apart, two doses } \\
\text { given } 24 \mathrm{~h} \text { apart }\end{array}$ \\
\hline Kook et al., (2002) [24] & USA & 16 & $19-44$ & Open label study & $0.75 \mathrm{mg}$ & Twice, taken $12 \mathrm{~h}$ apart \\
\hline Ngai et al., (2005) [32] & China & 2071 & 20-34 & Double-blind, randomized trial & $0.75 \mathrm{mg}$ & Every $24 \mathrm{~h} \&$ every $12 \mathrm{~h}$ \\
\hline Noé et al.., (2010) [35] & Chile & 388 & $18-38$ & $\begin{array}{l}\text { Prospective, open-label, single-drug, single dose, uncontrolled } \\
\text { clinical trial }\end{array}$ & $1.5 \mathrm{mg}$ & Once \\
\hline Raymond et al., (2006) [36] & USA & 120 & $18-38$ & Case-series study & $1.5 \mathrm{mg}$ & Once \\
\hline Sambol et al., (2006) [29] & USA & 22 & $13-16$ & Prospective, single-period, single center, open-label clinical trial & $0.75 \mathrm{mg}$ & Once \\
\hline Tremblay et al., (2001) [25] & South Africa & 24 & $18-26$ & Open, observer-blind, randomized study & $0.75 \mathrm{mg}$ & $\begin{array}{l}\text { Once, two doses given } 12 \mathrm{~h} \text { apart, two doses } \\
\text { given } 24 \mathrm{~h} \text { apart }\end{array}$ \\
\hline
\end{tabular}


Levonorgestrel has a prolonged half-life of around $24.4 \mathrm{~h}$. This rationalizes considering single-dose LNG emergency contraception as well as two doses taken 12$24 \mathrm{~h}$ apart. Pharmacokinetics of levonorgestrel was evaluated in a study using different dosing strategies in young, healthy, women [25]. This trial involved 24 women who were randomized to three levonorgestrel treatment groups: a single $0.75 \mathrm{mg}$ dose, two $0.75 \mathrm{mg}$ doses taken $12 \mathrm{~h}$ apart and two $0.75 \mathrm{mg}$ doses taken $24 \mathrm{~h}$ apart. The pharmacokinetic profiles were similar with all three treatments. Plasma concentrations of levonorgestrel were $9.6 \pm 0.38 \mathrm{nmol} / \mathrm{L}$ at $12 \mathrm{~h}$ and $6.2 \pm 0.53$ $\mathrm{nmol} / \mathrm{L}$ at $24 \mathrm{~h}$ after the first $0.75 \mathrm{mg}$ dose. Effective concentrations greater than $0.48 \mathrm{nmol} / \mathrm{L}$ were maintained for $48-60 \mathrm{~h}$ after the 12 and $24 \mathrm{~h}$ doses. The statistical investigations indicated no significant differences between groups in any of the pharmacokinetic parameters i.e. peak plasma concentration $\left(\mathrm{C}_{\max }\right)$, time to reach peak plasma concentration $\left(t_{\text {max }}\right)$, elimination rate constant $\left(\mathrm{K}_{\mathrm{el}}\right)$, half-life $\left(\mathrm{t}_{1 / 2}\right)$ and area under plasma concentration-time curve AUC.

An investigation on the pharmacokinetics of $1.5 \mathrm{mg}$ levonorgestrel in lactating women was also evaluated [28]. Twelve healthy breastfeeding participants received $1.5 \mathrm{mg}$ of LNG. For $72 \mathrm{~h}$ after dosing, the women abstained from nursing and fed their infants with milk which was frozen previously. Sequential milk and blood samples were collected and assessed for LNG and sex hormone binding globulin for $120 \mathrm{~h}$. LNG concentrations peaked in milk and plasma in 2-4 $\mathrm{h}$ and 1-4 $\mathrm{h}$ after dosing, respectively. Concentrations in milk were similar to those in plasma but were consistently lower. Projected infant exposure to LNG is $1.6 \mathrm{mg}$ on the day of dosing, $0.3 \mathrm{mg}$ on the second day and $0.2 \mathrm{mg}$ on the third day.

Another study examined plasma LNG concentrations and pharmacokinetics after oral administration of a single $0.75 \mathrm{mg}$ tablet [24]. Blood samples were collected sequentially over $72 \mathrm{~h}$ after dosing in a fasting state. $\mathrm{C}_{\max }$ of LNG was $14.1 \pm 7.9 \mathrm{ng} / \mathrm{mL}$ and $t_{\max }$ was $1.63 \pm 0.74 \mathrm{~h}$. Plasma concentration of LNG vs. time profiles were subjected to noncompartmental pharmacokinetic analysis for determining half-lives, apparent oral clearances $(\mathrm{Cl} /$ F), apparent volumes of distribution after oral administration (V/F) and mean residence time (MRT). The halflives ranged from $16.2 \mathrm{~h}$ to $32.3 \mathrm{~h}$ ( mean $=24.4 \pm 5.3 \mathrm{~h}$ ). The $\mathrm{Cl} / \mathrm{F}$ was $7.06 \pm 2.69 \mathrm{~L} / \mathrm{h}, \mathrm{V} / \mathrm{F}$ was $260 \pm 129 \mathrm{~L}$ and MRT was $27.8 \pm 5.2 \mathrm{~h}$.

In a different study, the pharmacokinetics of levonorgestrel between female adolescents and adults were compared [29]. A total of 259 levonorgestrel plasma concentrations in 22 female adolescents were investigated. On average, $C_{\max }$ was $6.72 \mathrm{ng} / \mathrm{mL}$ and occurred at $1.43 \mathrm{~h}$ after dosing. With a mean $9.5 \%$ contribution from extrapolation, average $\mathrm{AUC}_{0-\infty}$ was $86.1 \mathrm{ng} \mathrm{h} / \mathrm{mL}$. Mean CL/F was $145 \mathrm{ml} / \mathrm{min}$ and mean V/F was $267 \mathrm{~L}$ (Table 2). However, the data from an adult study (304 levonorgestrel plasma concentrations in 16 women) were also reconsidered. Adolescents had a mean levonorgestrel $\mathrm{C}_{\max }$ that was almost half of that detected in adults, with a mean ratio of 0.53 and a $90 \%$ CI (Table 2). The difference among the groups with respect to $\mathrm{AUC}_{0-\infty}$ was of borderline significance, with a mean ratio of 0.77. Also, the variance between the treatment groups with respect to $\mathrm{CL} / \mathrm{F}$ was marginally significant, with a mean ratio of 1.31 .

In addition, a group of investigators studied the pharmacokinetics of levonorgestrel where compared dosages were two $0.75 \mathrm{mg}$ doses taken $12 \mathrm{~h}$ apart, two $0.75 \mathrm{mg}$ doses taken $24 \mathrm{~h}$ apart, and a single $1.5 \mathrm{mg}$ dose [23]. In this trial, five women were randomized to be given all three treatments. They also received a four week washout period between the treatments. $t_{\max }$ was estimated 1.5-1.8 $\mathrm{h}$ after each of the two $0.75 \mathrm{mg}$ doses and $2.6 \mathrm{~h}$ after the single $1.5 \mathrm{mg}$ dose. $\mathrm{C}_{\max }$ after the $1.5 \mathrm{mg}$ single dose was about $50 \%$ greater than those after each $0.75 \mathrm{mg}$ dose. The second dose of both the 12 and $24 \mathrm{~h}$ double dose regimens revealed a slightly higher $\mathrm{C}_{\max }$ than that of the first dose. All three groups had similar mean LNG concentrations at $48 \mathrm{~h}$.

For finding an acceptable levonorgestrel regimen for emergency contraception, a two-dose regimen $0.75 \mathrm{mg}$ levonorgestrel $12 \mathrm{~h}$ apart and a single dose $1.5 \mathrm{mg}$ levonorgestrel were studied in 1118 Nigerian women [30]. Eleven pregnancies were reported, among them 7 were in the two-dose group and 4 in the single dose group. The relative risk of pregnancies was similar in both groups. Also, the estimated success rate of $86.80 \%$ in the $0.75 \mathrm{mg}$ group was significantly lower than the $92.99 \%$ for the $1.5 \mathrm{mg}$ group (Table 3). Minor side effects were reported such as nausea, vomiting, menorrhagia, lower abdominal pains, headache, breast tenderness and dizziness. Considerably more women who were in the highdose group reported headache, breast tenderness and heavy menstrual flow.

Another study considering the same dosage regimen among 3022 Nigerian women revealed similar effectiveness between the treatment groups. In the two-dose regimen, post-treatment pregnancy proportions were $0.57 \%$ whereas in the single-dose regimen, the proportion was $0.64 \%$ (Table 3). Most of the women menstruated in the first day of expected menses and the groups did not diverge regarding reported side effects. In general, the most common adverse event was nausea, which was accounted for about 22\% of participants in both groups. Some of the participants also experienced fatigue, dizziness, headache, breast tenderness and lower abdominal pain [31].

A different study compared the efficacy of two doses of $0.75 \mathrm{mg}$ levonorgestrel among 2071 Chinese women, 
Table 2 Pharmacokinetic comparison of different dosage regimens of levonorgestrel

\begin{tabular}{|c|c|c|c|c|c|c|c|c|c|c|}
\hline \multirow[t]{2}{*}{ Study (year) } & \multirow[t]{2}{*}{ Dose } & \multicolumn{8}{|c|}{$P_{k}$ parameters } & \multirow[t]{2}{*}{ Side effects } \\
\hline & & $\begin{array}{l}\mathrm{AUC}_{0-12} \\
(\mathrm{ng}-\mathrm{h} / \mathrm{ml})\end{array}$ & $\begin{array}{l}\text { AUC }_{0-24} \\
\text { (ng-h/ml) }\end{array}$ & $\begin{array}{l}\mathrm{AUC}_{0-\mathrm{t}} \\
(\mathrm{ng}-\mathrm{h} / \mathrm{ml})\end{array}$ & $\begin{array}{l}\mathrm{AUC}_{0-\infty} \\
(\mathrm{ng}-\mathrm{h} / \mathrm{ml})\end{array}$ & $\begin{array}{l}\mathrm{C}_{\max } \\
\text { (ng/ml) }\end{array}$ & $t_{\max }(h)$ & $\mathrm{K}_{\mathrm{el}}(1 / \mathrm{h})$ & $t_{1 / 2}(h)$ & \\
\hline Gainer et al., (2007) [28] & $1.5 \mathrm{mg}$ & 28.6 & 45.0 & 252.8 & 262.6 & 15.4 & 2.0 & -— & 29.3 & -— \\
\hline \multirow[t]{3}{*}{ Johansson et al., (2002) [23] } & $0.75 \mathrm{mg} \& 1.5 \mathrm{mg}$ & A:49.9 & $A: 81.3$ & A:139.5 & -— & A:7.9 & $A: 1.8$ & -— & A:43.7 & Nausea, sleepiness, headache. \\
\hline & & B:51.9 & B:73.2 & B:136.0 & & B:8.4 & B:1.4 & & B:32.0 & \\
\hline & & C:88.8 & C:130.8 & C:290.9 & & $C: 12.4$ & $C: 2.5$ & & C:43.3 & \\
\hline Kook et al., (2002) [24] & $0.75 \mathrm{mg}$ & -— & -— & 111.8 & 123.1 & 14.1 & 1.63 & 0.030 & 24.4 & Menstrual irregularity \\
\hline Sambol et al., (2006) [29] & $0.75 \mathrm{mg}$ & -— & -— & -— & 86.1 & 6.72 & 1.43 & -— & 21.2 & Headaches, dizziness, nausea, cramps \\
\hline Tremblay et al., (2001) [25] & $0.75 \mathrm{mg}$ & -— & -— & - - & 133.02 & - - & 2.27 & 0.042 & 21.72 & - - \\
\hline
\end{tabular}

$\mathrm{AUC}_{0 . t}$ : Area under the plasma concentration time curve calculated by the trapezoidal rule from time 0 until the last time point.

$\mathrm{AUC}_{0-\infty}$ : Area under the plasma concentration time curve corrected for the previous administration and extrapolated to infinity.

A: One tablet of $0.75 \mathrm{mg}$ levonorgestrel at time $-12 \mathrm{~h}$ and one tablet at time 0 .

B: One tablet of $0.75 \mathrm{mglevonorgestrel} \mathrm{at} \mathrm{time} 0$.

C: One tablet of $0.75 \mathrm{mg}$ levonorgestrel at time $-24 \mathrm{~h}$ and one tablet at time 0 . 
Table 3 Clinical statistics of levonorgestrel

\begin{tabular}{|c|c|c|c|}
\hline \multirow[t]{2}{*}{ Outcome measures } & \multicolumn{3}{|c|}{ Dosage regimen } \\
\hline & $1.5 \mathrm{mg}$ & $0.75 \mathrm{mg}$ (12 hourly) & $0.75 \mathrm{mg}$ (24 hourly) \\
\hline Pregnancy rate (\%) & $0.64^{(\mathrm{a})}-1.28^{(\mathrm{b})}$ & $0.57^{(b)}-2.0^{(c)}$ & $1.9^{(\mathrm{c})}$ \\
\hline Prevented fraction (\%) & $92.99^{(a)}-94.7^{(b)}$ & $75.0^{(\mathrm{c})}-95.2^{(\mathrm{b})}$ & $72.0^{(c)}$ \\
\hline $\begin{array}{l}\text { Side effects } \\
\text { (more prominent) }\end{array}$ & $\begin{array}{l}\text { Headache, breast tenderness, } \\
\text { heavy menses, fatigue, vomiting }\end{array}$ & $\begin{array}{l}\text { Nausea, diarrhea, lower abdominal } \\
\text { pain, delay of menses }\end{array}$ & Dizziness \\
\hline
\end{tabular}

given at either a 12 or $24 \mathrm{~h}$ interval, with the treatment period extended to $120 \mathrm{~h}$ after unprotected coitus [32]. The crude pregnancy rate was $2.0 \%$ in the $12 \mathrm{~h}$ group and $1.9 \%$ in the $24 \mathrm{~h}$ group. The prevented fraction of pregnancies was considered to be $75 \%$ in the $12 \mathrm{~h}$ group and $72 \%$ in the $24 \mathrm{~h}$ group (Table 3 ). The effectiveness of the $12 \mathrm{~h}$ regimen dropped significantly when there were further acts of coitus after treatment which was not observed in the $24 \mathrm{~h}$ group. The overall side-effects were mild and tolerable. Nausea and vomiting occurred in $10 \%$ of women whereas diarrhea and breast tenderness was significantly more common in the $12 \mathrm{~h}$ group. Also, the timing of menses did not vary between the two regimens.

A randomized, double-blind, placebo-controlled study evaluated to what degree the usual dose of levonorgestrel or a single dose, given in the follicular phase, affects the ovulatory process during the subsequent period of five days [33]. Time of treatment was determined by the diameter of the dominant follicle. Every woman had equivalent diameter allocated for all her treatments. Follicular rupture failed to take place during the five day period in $44 \%, 50 \%$ and $36 \%$ of cycles respectively with the standard, single dose and placebo. Ovulatory dysfunction occurred in 35\%, 36\% and 5\% of standard, single dose or placebo cycles, respectively, which is characterized by follicular rupture associated with absent, blunted or untimely gonadotropin surge.

Durand $M$ et al. [18] studied the effects of short-term administration of levonorgestrel at different phases of the ovarian cycle on the pituitary-ovarian axis, corpus luteum function and endometrium. The participants were studied during two menstrual cycles. Transvaginal ultrasound and serum LH were performed in both cycles from the detection of urinary LH until ovulation. During the complete luteal phase, serum estradiol and progesterone were measured. An endometrial biopsy was also taken, which revealed the endometrial histology as normal in all ovulatory-treated cycles. Finally, they suggested that "intervention of LNG with the mechanisms initiating the LH preovulatory surge depends on the stage of follicle growth". Thus, anovulation caused from disrupting the regular development and/or the hormonal activity of the developing follicle, only when LNG was given in the preovulatory phase.

Durand $\mathrm{M}$ et al. [34] analyzed endometrial expression and serum glycodelin concentrations during the luteal phase following oral levonorgestrel at various stages of the ovarian cycle. All the participants were studied during two consecutive cycles, namely a control cycle and the treatment cycle. During the luteal phase, serum progesterone and glycodelin were measured daily and an endometrial biopsy was taken for immuno-histochemical glycodelin-A staining. Levonorgestrel altered the luteal phase secretory pattern of glycodelin in serum and endometrium. The results accounted for the action of LNG in EC in those women who take LNG before the LH surge, based on the potent gamete adhesion inhibitory activity of glycodelin-A.

In a different study, $0.75 \mathrm{mg}$ LNG was administered twice right before ovulation, to test whether LNG acts as an emergency contraceptive by stopping the preovulatory LH surge and thereby delaying ovulation [19]. LNG was taken by twelve women on or before the day of the first significant increase in urinary LH in 12 cycles. The LH peak and the onset of next menses were delayed (16.8 days) in 30\% participants. Despite a normal LH peak and cycle length, one woman did not ovulate at all. LNG did not affect ovulation or the cycle length in the remaining eight participants, but the length of the luteal phase and the total luteal phase LH concentrations were considerably reduced.

Noé $\mathrm{G}$ et al. [35] aimed to evaluate whether levonorgestrel administered after ovulation is equally effective to LNG administered before ovulation. Blood samples were taken for analysis of $\mathrm{LH}$, estradiol and progesterone concentrations on the day of LNG administration and during five days' follow-up. Vaginal ultrasound analyses were also done for size of the leading follicle and/or corpus luteum. 122 women among the total of 388 women had coitus on fertile cycle days according to ultrasound and endocrine findings. 87 women were in days -5 to -1 and 35 women were in day 0 or beyond at the time of LNG intake. Estimated numbers of pregnancies among the 87 and 35 women were 13 and 7 respectively, while actually 0 and 6 pregnancies respectively occurred. 
Menstrual bleeding pattern after using $1.5 \mathrm{mg}$ levonorgestrel in a single dose was also examined [36]. The observed bleeding patterns after treatment were compared with usual patterns reported by the participants and with patterns observed in a previous study on women who had not taken any emergency contraceptives. Treatment in the first three weeks of the menstrual cycle significantly reduced that cycle as compared with both the usual cycle length and with the cycle duration in a comparison group. The magnitude of this outcome was greater if the pills were taken earlier. Additionally, the duration of the first menstrual period after treatment increased significantly with cycle week of treatment. This timeline was longer in participants who used the treatment than in those who did not.

\section{Discussion}

From the pharmacokinetic perspective, levonorgestrel was rapidly absorbed after either one single or two administrations at a 12 or $24 \mathrm{~h}$ time interval of levonorgestrel $750 \mu \mathrm{g}$ oral tablets. Also, the ADME profiles of levonorgestrel following the three different treatment regimens were similar [25]. The blood levels following administration of the first of two tablets (at $12 \mathrm{~h}$ interval) in the emergency contraceptive regimen were maintained for a sufficiently long period of time to prevent further unwanted fertilization [24]. Nevertheless, levonorgestrel was generally well tolerated by adolescents (single dose, $0.75 \mathrm{mg}$ ). The differences in observed total concentration were not likely to be seen in the unbound concentration. So, there is no reason based on pharmacokinetic data to expect that adolescents will experience greater adverse effects or lesser therapeutic effects after administration of the usual dose of LNG EC [29].

The AUC after administration of one single dose of $1.5 \mathrm{mg}$ LNG was greater than two doses of $0.75 \mathrm{mg}$ with a 12 or $24 \mathrm{~h}$ interval. Therefore, the administration of a single larger dose was more effective than the same amount of LNG divided into two doses [23]. On the other hand, nursing mothers might need EC but when a medication is taken by nursing women, the risks and benefits of taking that drug must first be weighed. Since LNG passes rapidly into the milk (single dose, $1.5 \mathrm{mg}$ ), the period of maximum LNG excretion in milk should be avoided and nursing should be discontinued and milk discarded for an interval of at least $8 \mathrm{~h}$, but not longer than $24 \mathrm{~h}$, after the use of EC [28].

From clinical point of view, the single $1.5 \mathrm{mg}$ regimen of levonorgestrel appeared more effective than the split doses of $0.75 \mathrm{mg}$ taken twice $12 \mathrm{~h}$ apart, not in terms of raw pregnancy rate or relative risk but in terms of effectiveness rate. The earlier each regimen was given after unprotected sexual intercourse, the more was the efficacy [30]. However, some authors claimed that the regimen of single-dose levonorgestrel was non-inferior and as well tolerated as the two-dose regimen. The patients requested EC did so because they were not using contraception at coitus. So it was suggested that levonorgestrel EC should be offered up to 5 days after unprotected intercourse [31]. In case of a $0.75 \mathrm{mg}$ regimen, the $24 \mathrm{~h}$ double dose levonorgestrel regimen was as effective as the $12 \mathrm{~h}$ regimen for emergency contraception up to $120 \mathrm{~h}$ after unprotected intercourse [32]. All the treatment regimens were well tolerated except some common side-effects and did not have any lasting effect on the individuals.

While assessing the mode of action of levonorgestrel, it was observed that LNG used for EC prevents pregnancy primarily by interfering with the ovulatory process and method failures are most likely due to treatment given too late to effect such intervention. No association was found between the usage of LNG and the risk of pregnancy complications, major congenital malformations or any other adverse pregnancy outcomes in case of its failure as an emergency contraceptive [37,38]. In addition, single administration of $0.75 \mathrm{mg}$ LNG was at least as effective as the standard two-dose regimen for inhibiting ovulation [33]. However, preovulatory administration of LNG suppresses ovulation in most but not all cases. Hinderance of LNG with the mechanisms involved in initiating the Luteinizing hormone preovulatory surge depends on the stage of follicular development. Thus, anovulation results from disrupting both normal maturation and hormonal natural action of a growing follicle [18]. Other plausible mechanism of actions of LNG such as retardation of the endometrium, interfering with sperm motility and changing cervical mucus [19]. This is because the in vitro effect of LNG as EC on sperm fertilizing capacity and embryo development remains poorly understood in various other potential studies [39-41].

Hormonal EC with LNG can alter endometrial glycodelin secretion in two important phases of the cycle when taken before the LH surge [42]. The first is during the fertile window and the second is the phase of uterine receptivity, both of which are of interest because of their antifertility activity [34]. However, it was observed that neither the glycodein level nor the proportion of motile sperm and cervical mucus is influenced by LNG [43]. Also, emergency contraception of levonorgestrel $(1.5 \mathrm{mg})$ in a single dose taken in the first 3 weeks of the menstrual cycle shortened that cycle. The degree of this effect was higher than the earlier the pills were taken. This regimen taken later in the cycle had no effect on cycle length but caused prolongation of the next menstrual episode [36]. So it is important to note that, LNG-EC is very effective in preventing pregnancy when it is administered before ovulation, but it is ineffective in 
such once fertilization has occurred [44]. That's why LNG-EC is less effective than regular contraceptives and its use should be controlled to emergency situations [35].

\section{Limitations}

The quality of several reports was poor. A number of reports lacked details about the study procedures, including the inclusion criteria, frequency of follow-up contacts, or method of pregnancy ascertainment. Seven reports did not specify the intended duration of follow-up, although five of these did present detailed information about continuation, discontinuation, and loss to follow-up in each month or 3 month period. Some studies did not mention the proportion of participants who may have continued to use the method after the last follow-up visit and who therefore may have had pregnancies that occurred during method use but that were not ascertained by the researchers. Studies were not able to explore the possibility that prevention of pregnancy may occur by some other natural means rather than effect of drug. We could not determine whether these shortcomings were the result of poor study quality or simply inadequate reporting. However, several studies that provided more than two thirds of the data in this review were well designed and clearly reported.

\section{Conclusions}

For emergency contraception, the US-FDA approves two doses of levonorgestrel $0.75 \mathrm{mg}$. The first dose should be taken within $72 \mathrm{~h}$ of unprotected intercourse and the second dosage, $12 \mathrm{~h}$ after the initial dosage. On the other hand, a single dose of levonorgestrel $1.5 \mathrm{mg}$ is also safe and effective for emergency contraception. Based on previous research findings, pharmacokinetic data and patient outcomes; the single dose strategy is warranted. Additionally, in case of two doses of levonorgestrel $0.75 \mathrm{mg}$, the second dosage can be taken within $24 \mathrm{~h}$ after the first dosage and the effectiveness of the drug would not be compromised. The clinical significance of this information is critical for clinicians instructing patients or prescribing levonorgestrel for emergency contraception.

\footnotetext{
Abbreviations

LNG: Levonorgestrel; LH: Lutenizing Hormone; P4: Day of maximal luteal serum progesterone; $C_{\text {max }}$ : Peak plasma concentration; $t_{\text {max }}$ : Time to reach peak plasma concentration; $K_{e}$ : Elimination rate constant; $t_{1 / 2}$ : Half-life; AUC: Area under plasma concentration-time curve; $\mathrm{AUC}_{0-\mathrm{t}}$ : Area under the plasma concentration time curve calculated by the trapezoidal rule from time 0 until the last time point; $\mathrm{AUC}_{0-\infty}$ : Area under the plasma concentration time curve corrected for the previous administration and extrapolated to infinity; Cl/F: Apparent oral clearances; V/F: Apparent volumes of distribution after oral administration; MRT: Mean residence time; EC: Emergency contraception/contraceptive; ADME: Absorption, distribution, metabolism, excretion; FDA: Food and drug administration.
}

\section{Competing interests}

The authors have no competing financial interests in relation to the work described.

\section{Authors' contributions}

This work was carried out in collaboration between all authors. Author MS designed the study and wrote the protocol and wrote the first draft. Authors MMR, AZ, MMAA and MMNU searched the literatures and collected data and wrote the first draft of the manuscript. Author HMR finalized the manuscript. All authors read and approved the final manuscript.

\section{Acknowledgements}

We are extremely thankful to all who gave their advice in the preparation of this paper. The authors also grateful to Dr. Mst. Shahnaj Pervin for revising the manuscript critically.

\section{Source(s) of funding}

The authors did not receive any financial help from any person or institutions.

\section{Author details}

${ }^{1}$ Department of Pharmaceutical Sciences, North South University, Dhaka 1229, Bangladesh. Department of Pharmacy, University of Chittagong, Chittagong, Bangladesh.

Received: 7 August 2013 Accepted: 30 March 2014

Published: 4 April 2014

\section{References}

1. The Lancet Editorial: After the morning after and the morning after that. Lancet 1995, 345:1381-1382.

2. Cayley J: Emergency contraception. BMJ 1995, 311:762-763.

3. Pearson VA, Owen MR, Phillips DR, Gray DJ, Marshall MN: Pregnant teenagers' knowledge and use of emergency contraception. BMJ 1995, 310:1644.

4. Pillaye J: Morning-after birth control. Lancet 1995, 346:251-252.

5. Trussell J, Stewart F: The effectiveness of postcoital hormonal contraception. Fam Plann Perspect 1992, 24(6):262-264

6. Yuzpe AA, Lancee WJ: Ethinyl oestradiol and dl-norgestrel as a postcoital contraceptive. Fertil Steril 1977, 28:932-936.

7. Yuzpe AA, Smith RP, Rademaker AW: A multicenter clinical investigation employing ethinyl oestradiol combined with dl-norgestrel as a postcoital contraceptive agent. Fertil Steril 1982, 37:508-513.

8. Sánchez-Borrego R, Balasch J: Ethinyl oestradiol plus dl-norgestrel or levonorgestrel in the Yuzpe method for post-coital contraception: Results of an observational study. Hum Reprod 1996, 11(11):2449-2453.

9. Camp SL, Wilkerson DS, Raine TR: The benefits and risks of over-thecounter availability of levonorgestrel emergency contraception. Contracept 2003, 68:309-317.

10. Coukell AJ, Balfour JA: Levonorgestrel subdermal implants: a review of contraceptive efficacy and acceptability. Drugs 1998, 55(6):861-887.

11. Van Look PF, von Hertzen H: Emergency contraception. Br Med Bull 1993, 49:158-170

12. Goldstuck ND, Steyn PS: The intrauterine device in women with diabetes mellitus type I and II: a systematic review. ISRN Obstet Gynecol 2013, 2013:1-6.

13. World Health Organization Task Force on Post-Ovulatory Methods for Fertility Regulation: Randomized controlled trial of levonorgestrel versus the Yuzpe regimen of combined oral contraceptives for emergency contraception. Lancet 1998, 352:428-433.

14. Piaggio $G$, von Hertzen $H$, Grimes DA, van Look PF: Timing of emergency contraception with levonorgestrel or the Yuzpe regimen. Lancet 1999, 353:721.

15. Müller AL, Llados CM, Croxatto HB: Postcoital treatment with levonorgestrel does not disrupt postfertilization events in the rat. Contracept 2003, 67:415-419.

16. Marions L, Hultenby K, Lindell I, Sun X, Stabi B, Gemzell Danielsson K: Emergency contraception with mifepristone and levonorgestrel: mechanism of action. Obstet Gynecol 2002, 100:65-71.

17. Croxatto HB, Devoto L, Durand M, Ezcurra E, Larrea F, Nagle C, Ortiz ME, Vantman D, Vega M, von Hertzen H: Mechanism of action of hormonal preparations used for emergency contraception: a review of the literature. Contracept 2001, 63:111-121.

18. Durand M, Cravioto MC, Raymond EG, Durán-Sánchez O, Cruz-Hinojosa MDL, Castell-Rodríguez A, Schiavon R, Larrea F: On the mechanisms of 
action of short-term levonorgestrel administration in emergency contraception. Contracept 2001, 64:227-234.

19. Hapangama D, Glasier AF, Baird DT: The effects of peri-ovulatory administration of levonorgestrel on the menstrual cycle. Contracept 2001, 63:123-129.

20. Kesserü E, Garmendia F, Westphal N, Parada J: The hormonal and peripheral effects of d-norgestrel in postcoital contraception. Contracept 1974, 10:411-424.

21. Coutinho E, Berer M, Delano G, Ellertson C, Garza-Flores J, Glasier A, Greenslade F, von Hertzen H, Huezo C, Kapoor I, Ketting E, Ladipo OA, Lewis J, Manguyu F, Mati JKG, Robinson E, Shelton J, Segal S, Senanayake P, Tadlar F, van Look PF, Widyantoro N, Winikoff B, Billan X: Consensus statement on emergency contraception. Contracept 1995, 52:211-213.

22. Nilsson CG, Lahteenmaki P, Luukkainen T: Patterns of ovulation and bleeding with a low levonorgestrel-releasing intrauterine device. Contracept 1980, 21:155-164.

23. Johansson E, Brache V, Alvarez F, Faundes A, Cochon L, Ranta S, Lovern M, Kumar N: Pharmacokinetic study of different dosing regimens of levonorgestrel for emergency contraception in healthy women. Hum Reprod 2002, 17:1472-1476.

24. Kook K, Gabelnick H, Duncan G: Pharmacokinetics of levonorgestrel $0.75 \mathrm{mg}$ tablets. Contracept 2002, 66:73-76.

25. Tremblay D, Gainer E, Ulmann A: The pharmacokinetics of $750 \mu \mathrm{g}$ levonorgestrel after administration of one single dose or two doses at 12 or 24 h interval. Contracept 2001, 64:327-331.

26. Back DJ, Grimmer SFM, Rogers S, Stevenson PJ, Orme ML: Comparative pharmacokinetics of levonorgestrel and ethinylestradiol after intravenous, oral, and vaginal administration. Contracept 1987, 36:471-479

27. Fotherby K: Levonorgestrel: clinical pharmocokinetics. Clin Pharmacol 1995, 28:203-215.

28. Gainer E, Massai R, Lillo S, Reyes V, Forcelledo ML, Caviedes R, Villarroel C, Bouyer J: Levonorgestrel pharmacokinetics in plasma and milk of lactating women who take $1.5 \mathrm{mg}$ for emergency contraception. Hum Reprod 2007, 22(6):1578-1584.

29. Sambol NC, Harper CC, Kim L, Liu CY, Darney P, Raine TR: Pharmacokinetics of single-dose levonorgestrel in adolescents. Contracept 2006, 74:104-109.

30. Arowojolu AO, Okewole IA, Adekunle AO: Comparative evaluation of the effectiveness and safety of two regimens of levonorgestrel for emergency contraception in Nigerians. Contracept 2002, 66:269-273.

31. Dada OA, Godfrey EM, Piaggio G, von Hertzen H: A randomized, doubleblind, noninferiority study to compare two regimens of levonorgestrel for emergency contraception in Nigeria. Contracept 2010, 82:373-378.

32. Ngai SW, Fan S, Li S, Cheng L, Ding J, Jing X, Yu Ng EH, Ho PC: A randomized trial to compare $24 \mathrm{~h}$ versus $12 \mathrm{~h}$ double dose regimen of levonorgestrel for emergency contraception. Hum Reprod 2005, 20:307-311.

33. Croxatto HB, Brache V, Pavez M, Cochon L, Forcelledo ML, Alvarez F, Massai $R$, Faundes A, Salvatierra AM: Pituitary-ovarian function following the standard levonorgestrel emergency contraceptive dose or a single 0.75 mg dose given on the days preceding ovulation. Contracept 2004, 70:442-450

34. Durand M, Seppala M, Cravioto MC, Koistinen H, Koistinen R, GonzálezMacedo J, Larre F: Late follicular phase administration of levonorgestrel as an emergency contraceptive changes the secretory pattern of glycodelin in serum and endometrium during the luteal phase of the menstrual cycle. Contracept 2005, 71:451-457.

35. Noé G, Croxatto HB, Salvatierra AM, Reyes V, Villarroel C, Muñoz C, Morales $G$, Retamales A: Contraceptive efficacy of emergency contraception with levonorgestrel given before or after ovulation. Contracept 2010, 81:414-420.

36. Raymond EG, Goldberg A, Trussell J, Hays M, Roach E, Taylor D: Bleeding patterns after use of levonorgestrel emergency contraceptive pills. Contracept 2006, 73:376-381.

37. De Santis M, Cavaliere AF, Straface G, Carducci B, Caruso A: Failure of the emergency contraceptive levonorgestrel and the risk of adverse effects in pregnancy and on fetal development: an observational cohort study. Fertil Steril 2005, 84(2):296-299.

38. Zhang L, Chen J, Wang Y, Ren F, Yu W, Cheng L: Pregnancy outcome after levonorgestrel-only emergency contraception failure: a prospective cohort study. Hum Reprod 2009, 24(7):1605-1611.
39. Hermanny A, Bahamondes MV, Fazano F, Marchi NM, Ortiz ME, Genghini MHRR, Croxatto HB, Luis Bahamondes L: In vitro assessment of some sperm function following exposure to levonorgestrel in human fallopian tubes. Reprod Biol Endocrinol 2012, 10:8.

40. Brito KS, Bahamondes L, Nascimento JA, de Santis L, Munuce MJ: The in vitro effect of emergency contraception doses of levonorgestrel on the acrosome reaction of human spermatozoa. Contracept 2005, 72(3):225-228.

41. Munuce MJ, Nascimento JA, Rosano G, Faúndes A, Saboya-Brito K, Bahamondes $L$ : In vitro effect of levonorgestrel on sperm fertilizing capacity and mouse embryo development. Contracept 2005, 72(1):71-76.

42. Devoto L, Fuentes A, Palomino A, Espinoza A, Kohen P, Ranta S, von Hertzen $\mathrm{H}$ : Pharmacokinetics and endometrial tissue levels of levonorgestrel after administration of a single 1.5-mg dose by the oral and vaginal route. Fertility and Sterility 2005, 84(1):46-51.

43. Do Nascimento JAA, Seppala M, Perdigao A, Espejo-Arce X, Munuce MJ, Hautala $L$, Koistinen R, Andrade L, Bahamondes L: In vivo assessment of the human sperm acrosome reaction and the expression of glycodelin- $A$ in human endometrium after levonorgestrel-emergency contraceptive pill administration. Hum Reprod 2007, 22(8):2190-2195.

44. Novikova N, Weisberg E, Stanczyk FZ, Croxatto HB, Fraser IS: Effectiveness of levonorgestrel emergency contraception given before or after ovulation - a pilot study. Contracept 2007, 75(2):112-118.

doi:10.1186/1472-6874-14-54

Cite this article as: Shohel et al:: A systematic review of effectiveness and safety of different regimens of levonorgestrel oral tablets for emergency contraception. BMC Women's Health 2014 14:54

\section{Submit your next manuscript to BioMed Central and take full advantage of:}

- Convenient online submission

- Thorough peer review

- No space constraints or color figure charges

- Immediate publication on acceptance

- Inclusion in PubMed, CAS, Scopus and Google Scholar

- Research which is freely available for redistribution 